\title{
Comparative Analysis between Traditional and Modern Criminal Procedure Code
}

\author{
Sajad Fatahi Zafarqandi ${ }^{1} \&$ Majid Vaziri ${ }^{1}$ \\ ${ }^{1}$ Tehran Azad University, Central branch, Iran \\ Correspondence: Sajad Fatahi Zafarqandi, Tehran Azad University, Central branch, Iran. E-mail: \\ Mahde.aa52@gmail.com
}

Received: September 7, 2016

Accepted: October 9, 2016 Online Published: October 30, 2016

doi:10.5539/jpl.v9n9p97

URL: http://dx.doi.org/10.5539/jpl.v9n9p97

\begin{abstract}
The criminal procedure code has been regarded as one of the most important and substantial codes in every state among which a major part of the criminal general discipline and criminal justice is enforced. The judicial, procedural systems and criminal procedure code regulations in Iran have been transformed during the previous decade. These transformations caused some irregularities and anomalies in judicial system and citizenship rights state in addition to organizing the criminal procedure code such that everyone witnessed these anomalies at the time of the courts' law and courts' resorting law. The changed in qualification of the prosecuting entity and the related section, carefully explaining the duties and the authorities of the prosecutor and investigator, allocating the enforcements due to security and legal responsibilities, practical exclusion of the investigating judge and the responsibilities of judicial court administrator and its transfer to the investigator and prosecutor, organizing the prosecutors' and judicial references and judges' duties and responsibilities, and so forth as well as attempting to harmonize the criminal procedure system with fair procedure system principles codified in international human rights declaration, international political and civil rights treaty and other relevant human rights documents in line with respecting for all human rights liberties and rights as identified rules in international rights and as a result, highlighting the human right approach to this issue and tendency to practical mixed investigation and procedure system.
\end{abstract}

Keywords: criminal procedure code, procedure principles, rules and regulations

\section{Introduction}

Criminal procedure code is a set of norms, rule, regulations and principles which are enforced following a crime committed so that the qualified legal references and authorities would take action in order to secure the society and preserve the human rights by enforcing the justice relative to detection, prosecution, investigation and legal verdict issuance and implementing the verdict using the norms and regulations. The criminal procedure code first was approved in 1911 entitled temporary criminal courts code by national parliament's justice commission. It was a law including 492 articles which finally with 506 articles was communicated to the minister of justice by the government in 1911 and was implemented. Of course, it should be mentioned that in approving this law, Hasan Modares played an important role. This law governed the criminal procedures over 60 years and after the Islamic revolution and the attempts in order to reform and modify this law and make it conform to religious rules, there were actions taken by the judiciary branch chief on the basis of which the law of revolution and general courts establishment in 1994 and criminal procedure code relative to mentioned law based on elimination of the court system in 1999 were approved. At the time of the Shahrudi's presidency in judiciary branch, due to some problems in traditional law (such as eliminating the courts), it was decided to modify this law and the preparation and codification of bill draft of criminal procedure code was started in 2000 by Tehran court selected board and then revised and approved by the judiciary branch's higher board and after 2 years and several months, the code draft with 357 articles in 6 chapters and 13 sections and different discussions was codified. In 2002, June, this draft was sent to the judiciary branch office and in second half of the 2002, it was revised and refined in previous form and chapters and sections including 342 articles. This bill was revised by parliament and judiciary branch and this issue caused a long time to approve it so that after Amoli Larijani was appointed as the chief of judiciary branch, the judiciary branch's legal vice chairman again revised this law and the justice ministry also seriously took its part to finalize this bill and eventually, its final version was communicated to the government. Finally, 
the criminal procedure code bill was approved by Islamic parliament in 2013, February and approved by Guardian council in 2013 and approved including 570 articles and 230 notes in 2013. The judicial and legal commission of Islamic parliament also based on the principle 85 of constitution which was communicated to the Islamic parliament as a bill, implements the law as a pilot implementation for 3 years after the agreements and it was published in official gazette in a letter numbered 20135 in 2014, March, after it was approved by the guardian council in 2013. In accordance with article 569, 6 months after its publish in official gazette, it would be binding. In this article, it is attempted to investigate the achievements and innovations of modern law and investigate and compare it from a legal perspective. However, the new law in comparison to the traditional one has some strengths and weaknesses which are admirably predicted. This law is more explicit and cohesive. The prosecuting, investigating and procedure reference are distinguished more explicitly and their duties and authorities are addressed individually. The characteristics of the new criminal procedure code are as follow:

- Focusing on fair procedure principles: in primary articles of this code, the necessity for respecting the fair procedure important principles are stipulated and emphasized. Article 2 explains the legal procedure principle. In article 3, neutrality and independence of the judicial references on one hand and its lack of justification is mentioned on the other hand. The openness of the court is also another pillar of the fair procedure mentioned in article 352 is stipulated. The innocence principle and its effects are stipulated in article 4 and in article 7, the necessity to respect for the codified citizenship rights in law and legal liberties and citizenship rights are emphasized.

- Normative, transparency and reducing the abuse opportunities: the criminal procedure code, 20113, also like Islamic criminal code, 2013, attempted in different cases to reduce the ambiguities and opportunity for abuse by explaining the terms and norms transparently. Increasing the hedges to double level in article 217 and explaining how to issue and change or transform it in following articles and cancelling the temporary arrest reduced the abuses. Article 466 attempted to ban and at least normalizing the procedures out the determined instance. In articles 28 and 29, the judiciary officers are accurately defined and in article 30, it is stipulated that qualifying the officers depends on trustworthiness in addition to learning necessary skills and passing the educational terms in judiciary reference and achieve the judiciary officers' card and reliability. The researches conducted and action taken by persons without this card is banned and lack legal effect. Also, in new code, more explicit terms are used than traditional one such as prosecuting the accused person instead of the criminal person in article 1, arrest warrant for hearing instead of guilt in article 265 and so forth. Some terms also such as spiritual loss were explained and defined for the first time in this code (note 1, article 14).

- More highlighted role of kthe attorneys: the attorney's presence as an expert person in legal and criminal affairs can guarantee the parties rights achievement and correct law enforcement. In new law in accordance with article 5, the accused person has to have access to attorney and article 48 stipulates that as the prosecuting starts, the accused party can request for attorney. The attorney has to visit with the person considering all privacy policies of the negotiations and investigations and can provide the written consideration after visiting the accused party in order to record them in the case. The attorney's presence is more highlighted and organized tha the traditional law. Article 190 stipulated that the accused party can bring an attorney in primary investigations. This right has to be communicated to the accused party by investigator before the investigation. If the accused party is summoned, this right is included in the summon letter. The attorney can explain the necessary issues related to the fact detection and defend his client or enforce the law based on the guilt information and reasons. The attorney's statements would be written in proceedings. The note 1 of this article predicted an effective enforcement for this provision. Deprivation of the right of having attorney or lack of communicating this right to the accused party causes the investigations to be ineffective. But in reformations o the 2015, the enforcement of this note changed to prediction of the disciplinary punishment for the judicial authority. Lack of validity of the investigations was a type of preserving the right to have attorney for accused party. The disciplinary prosecutions as to be its complementing section but replace it.

Moreover, in accordance with note 2 , in crimes its punishment would be death or life imprisonment; if the accused didn't introduce his attorney in primary stages of investigation, the investigator would select him an attorney. Therefore, even in primary investigations in some cases the attorney is necessary. On the other hand, in accordance with article 38, the court officers have to inform the plaintiff about his rights to be consulted and legal assistance. Considering the victim's rights and attempting to compensate for it is among the positive points of this law. In accordance with note 2 of article 13 and article 348 considering the article 302, the cases necessitate the presence of attorney in investigation, in addition to death penalty and life imprisonment, are imprisonment level 2-3 crimes as well as other cases in which the person got insanity before issuance of the decisive verdict which were increased in new law. The number of attorneys in primary investigations is one 
person as before. Unfortunately, in note of article 48 in modifications of the $2014 \mathrm{~m}$ March, it is stated that: in crimes against the national or international security, as well as organized offenses which are punished based on article 302, the parties would select their attorney(s) among the judiciary official attorneys confirmed by the judiciary branch. The names of the attorneys are communicated by the chief of judiciary branch. Selective attorney having entitlement in judiciary references is one of the main individuals' rights which is stipulated in article 25 of the constitution as well as international documents. This note is not only in conflict with accused party's rights and favor, but also is criticized in term of attorney profession reasoning violation as well as in term of discrimination between attorneys and selecting them by the judiciary branch chief. This note is expected to be modified as soon as possible in a logical manner and in line with fair procedure norms. Finally, in a section of the article 354 it is stated that: if the disruptor was from the lawsuit party, the court would note him to respect the court's order and if didn't do so, he would be fired and introduced to disciplinary attorney court. This statement is deemed a significant advancement in respecting the defense right and attorney's independence and the attorney relative to the note 2 of article 188 of CPC, approved in 1999 and article 101 of civil procedure code, approved in 2000 which was permitted to arrest the attorneys. In article 471 also the attorneys are permitted like judges to request the revision of the Supreme Court on the issued verdict through the chief of the Supreme Court and attorney general.

- Independency increase for investigator from prosecutor: in new law, the investigator's independence in considered significantly by the legislator. One of the most important issues is the lack of returning the case from the prosecutor. However, in article 262 of traditional law also the supreme court branches and other courts are stipulated that after the case referred to a branch it would not be possible to retake it and refer it to other branch, but the law approved in 1999 is silent about this issue due to kack of court at the time this law was codified related to the referring to the prosecuting branch and in subsequent law and its reformations, this is not noted. Therefore, it was possible to interpret differently and abuse the law and it causes that in some cases, the prosecutor decided to retake the case from an investigating branch and refer it to the other branch. Article 339 stated the rule that after the case referred, it would not be possible to take it back from the branch referred to and give it to the other branch. Note 1 included the investigation as note 2 stated its enforcement. In other issues also the investigator and prosecutor's independence preserve are considered which are explained in following section.

- The mediation and compromise duty: in criminal procedure code approved in 2013 as well Islamic criminal code of 2013, the victim's loss compensation is considered particularly and in this regard, by predicting privileges, the accused party is encouraged to compensate for the victim's loos or satisfy hi,. In article 82 of CPC, in imprisonment punished crimes (level 6-8), the judicial authority can give the accused party 2 month to satisfy the plaintiff or compensate for his loss by respecting the conditions of accused party's request and victim's agreement. In order for parties to compromise, the judge can refer the case to the dispute resolution council in agreement of parties or other institute as mediating institution. This is possible when the plaintiff's consent (victim) is accepted in forgivable crimes. If the crime was not forgivable or the victim is compensated for his loss and the victim consented and forgave and the accused party lack offensive background, the judicial authority can suspend his prosecution from 6 months to 2 years based on the victim's agreement and require him to take ordered actions. Based on article 83, the written result of the mediation would be communicated to the judge in order to for further actions. In case of agreement, parties' obligations and how to fulfill then have to be included.

- Recognition of indictment right and NGO's follow-up: NGOs can play an important role in human demands and requests follow-up. So far, the law didn't let these NGOs involving directly. Article 66 in this regard states: NGOs with statute about supporting the adolescents and children, patients and mental or physical disable persons, environment, natural resources, cultural heritages, public hygiene and supporting for citizenship rights can indict related to the crimes committed against abovementioned issues and participate in court. In text approved in 2013, the protest right to the issued verdicts is predicted too which is removed in text approved in 2015 and the authorities of NGOs to indict and participate in court are limited.

- Electronic procedure: making use of the technology can accelerate the investigations, financial and human sources economization. But, this issue has to be normative and logical and due to weaknesses of the system or governing regulation, it should not provide the basis for violation of the individuals' rights with more costs imposed on them. Article 175 states that: employing computer and telecommunication systems such as email, remote video conference, telephone etc. in order to complain or sue lawsuit refer the case, summoning accused party, communicating the judicial letters as well as judicial representation are permitted by respecting the e-procedure codes. In article 465 also the electronic procedure is mentioned, but its conditions are not explained. But in note of article 175 it is stated that: the conditions and how to employ the computer and telecommunication systems is subjected to this article which is prepared within 6 months of implementing this law by justice 
minister and would be approved by judiciary branch. In present conditions in which it is necessary to submit the lawsuits and complains through judicial services system, practically there are higher costs and submission prolongation. Even the attorneys are not permitted to submit the lawsuit from their office and have to pay more costs and spend long times in judiciary services offices. Moreover, if there was any problem with system or its crowdedness, the legal deadline is expired and the individuals' rights would be violated. Anyway, first these limitations have to be determined and solutions have to be found and second, these services should be for easy actions by people not increasing the time and costs of investigation. The important section of the criminal procedure code of the electronic procedure and armed forces approved in 2013, October, is allocated to e-procedure which is more explained elsewhere. The mentioned law included in sections 8-11 of the CPC consists of armed force criminal procedure code, electronic procedure, computer criminal procedure code and legal persons' criminal procedure code. In this paper only the articles are mentioned.

- Providing practical necessities for reasonability of the court and Supreme Court's investigations: necessity of reasonability of the courts' verdicts in addition to constitution is predicted in general laws. But, lack of reasonability of the verdicts has always been a problem with judicial system. In a reasonable and sound verdict, all parties' reasons and their attorney's objections have to be answered reasonably and in a persuasive manner and making use of general terms such as unjustified defenses, baseless statements and like them are not reason. In criminal procedure code approved in 2013, it is attempted to encourage the Supreme courts to issue reasonable verdicts. In this regard, article 395 predicted the requirement to include the minority reasonable statements. Moreover, based on a part of article 469: the attorney general or his representative would state their comment be participating in the branch in a reasonable, documented and written form related to the violation or insistence on the objected verdict or the punishment. Then, the branch members would make decision based on the case contents and the reports stated by including the view of the attorney general or his representative in the verdict issued. These issues are all attempts to make the judicial verdicts more reasonable. However, necessity to respond the request and defenses of parties and their attorneys in a reasonable manner is inevitable which is not practiced in Iranian judicial system.

- Change of the judicial references and implicit authorization to substantial investigation by Supreme Court: The criminal courts 1 and 2 replaced the criminal general courts and province criminal courts. The revolution court is established in presence of 3 judged about important crimes. Numerous judges in this court are in order to enforce the justice properly. The crimes which are investigated in Supreme Court have increases significantly in accordance with article 428 and if the Supreme Courts was not increased in number, investigation in this court would face a crisis. In contrast to article 264 of traditional laws, article 468 of PCP approved in 2013 doesn't stipulate the form of the court's investigation, but based on paragraph B of article 469 , if the punishment verdict was issued disregard of the reasons and evidences of the parties, it would be canceled. Therefore, the Supreme Court investigates the evidence substance and the parties' defenses and investigates substantially.

- Differentiating the prisons and prisoners and the accused persons from each other: in line with individualizing the punishments and reducing the effects of the imprisonment which has always been criticized, in notes of kthe article 513 the differentiation between there prisons and prisoners is predicted. Note 1 stated that prisons are classified to closed, open and semi-open prisons, profession training, and occupational and securing and training centers such as correction and training center for adolescents and children. Then note 2 , states about the prisoners classification: except for cases stipulated in court verdict or the law, the criminals have to be imprisoned based on their type and period of punishment, background and personality, in accordance with the decision made by classification council and approval of the judge. If this note was correctly and properly enacted, there would be significant advance in this regards. Stating the strengths of this issue doesn't mean that there is no problem. For example, article 380 stated about the necessity of communicating the verdict to parties or their attorney and there would be ambiguities and may cause abuse. Moreover, in note 2 of this article the communication is limited and transcription is permitted only and even it is not detected who is to determine it?

\section{Conclusion}

Investigating the new criminal procedure code and its innovations and achievements indicate the legislators' attempt to change traditional legal and judicial approached in recognizing, respecting and enforcing the substantial rights and legal liberties for people and citizens, considering the narrow interpretation in favor of the accused party and respecting the principles and norms of the citizenship rights and human rights in spite of the criticisms and attempted to achieve a fair procedure process for plaintiff, victim, accused, witness, attorney and the society as so forth in criminal procedure process. In this law, in addition to removing many limitations and barriers related to the accused rights and defense, the principle manner is to have an attorney and defend the accused party' rights as his client and necessity of communicating this legal right to the accused by the judge and 
judiciary officers in all criminal affairs. In this regard, by strengthening the role and place of the attorney in accused's rights and strengthening the fair procedure and like that as well as attempts to make criminal procedure system conform to fair procedure system stated in international human right declaration, international civil and political rights treaty and other human rights documents, the mixed procedure process has been provided in order to respect for the human substantial and legal liberties and rights and highlighting the human rights approach to this issue. The legislator indicated his tendency to eliminate the problems and shortcomings of the traditional law and present problems in criminal procedure process in judicial systems. However, the legislator positively views the substantial changes and their value in legal approach to the mentioned processes, there are problems addressed in enforcing this law which made legal and practical issues in this regard and would impose high material and spiritual costs on the society.

\section{References}

Ashuri, M. (n.d.). series of articles, criminal justice (1st ed.). Ganje Danesh.

Khaleqi, A. (2014). the points of the criminal procedure code (1st ed.). Shahre Danesh publication.

Khazani, M. (1998). criminal process, series of articles (1st ed.). Ganje Danesh.

Naser Zadeh, H. (1994). criminal procedure code (1st ed.). Agah.

\section{Copyrights}

Copyright for this article is retained by the author(s), with first publication rights granted to the journal.

This is an open-access article distributed under the terms and conditions of the Creative Commons Attribution license (http://creativecommons.org/licenses/by/4.0/). 